\title{
Project-collective management as a development factor of the school staff
}

\section{Gestão de projeto coletivos como fator de desenvolvimento da equipe escolar}

\section{La gestión colectiva de proyectos como factor de desarrollo del equipo escolar}

\author{
Alexey Mikhalovich Kamenskiy ${ }^{1}$ (D), Sergey Nikolaevich Kariagin ${ }^{2}$ (D)
}

\begin{abstract}
1 State Educational Institution of Higher Professional Education "Leningrad Regional Institute of Education Development", Saint-Petersburg, Russian Federation.

${ }^{2}$ State budgetary educational institution "Boarding school No 289 with in-depth study of the subject "Physical culture" of the Krasnoselsky district of Saint-Petersburg”, Saint-Petersburg, Russian Federation.
\end{abstract}

Corresponding author:

Alexey M. Kamenskiy

Email: kamenskyi@mail.ru

How to cite: Kamenskiy, A. M. \& Kariagin, S. N. (2021). Project-collective management as a development factor of the school staff. Revista Tempos e Espaços em Educação, 14(33), e15619. http://dx.doi.org/10.20952/revtee.v14i33.15619

\section{ABSTRACT}

The article deals with the organization of the collective project activities at school. Leading projects, described in the article, fit into the program for the extracurricular work development. We emphasized the importance of social partnership, interaction with creative unions of the city, public associations, sports societies, etc. A new effective model of interaction between subjects of educational activity is proposed in the framework of the long-term socially-oriented projects implementation, containing educational, cultural and developmental potential. As an additional effect, we noted the development of leadership abilities of participants in educational relations.

Keywords: Collectivity. Project-collective management. Development of the school staff. Social partnership. Development of individuality.

\section{RESUMO}

O artigo trata da organização das atividades do projeto coletivo na escola. Os projetos líderes, descritos no artigo, enquadram-se no programa de desenvolvimento do trabalho extracurricular. Enfatizamos a importância da parceria social, interação com sindicatos criativos da cidade, associações públicas, sociedades desportivas, etc. Um novo modelo eficaz de interação entre os sujeitos da atividade educacional é proposto no âmbito da implementação de projetos de longo prazo de orientação social, contendo potencial educacional, cultural e de desenvolvimento. Como 
efeito adicional, notamos o desenvolvimento das habilidades de liderança dos participantes nas relações educacionais.

Palavras-chave: Coletividade. Gestão de projetos coletivos. Desenvolvimento do pessoal da escola. Parceria social. Desenvolvimento da individualidade.

\section{RESUMEN}

El artículo trata de la organización de las actividades del proyecto colectivo en la escuela. Los proyectos líderes, descritos en el artículo, encajan en el programa para el desarrollo del trabajo extraescolar. Destacamos la importancia de la colaboración social, la interacción con los gremios creativos de la ciudad, asociaciones públicas, sociedades deportivas, etc. Se propone un nuevo modelo eficaz de interacción entre sujetos de la actividad educativa en el marco de la ejecución de proyectos de largo plazo con orientación social, que contiene potencial educativo, cultural y de desarrollo. Como efecto adicional, notamos el desarrollo de habilidades de liderazgo de los participantes en las relaciones educativas.

Palabras clave: Colectividad. Proyecto-gestión colectiva. Desarrollo del personal escolar. Colaboración social. Desarrollo de la individualidad.

\section{INTRODUCTION}

The study topic is relevant for the international educational community, since the growing trend of the human life autonomization carries the danger of disunity of the human community. The project form of collective activity is aimed at uniting people. Our understanding of an educational project is based on the needs and capabilities of a modern mainstream school, where, on the one hand, each student should be engaged in project activities, on the other hand, allocated human, material, financial resources for achieving this goal are extremely limited. By an educational project, we mean a purposefully organized process of the child's independent mastering of new knowledge, which results in a useful product. Thus, the importance of the presence of two obligatory components, like independent cognition and social benefit in the project activity becomes obvious. If one thing is missing, then in the strict sense such activity is not an educational project. If the child worked on writing an abstract, then this work remains just an abstract. If the children put on a play, then it will be nothing more than a school play. But at the same time, almost any child's activity can be given a project form. If during the preparation of the play the children studied the era, prepared the scenery, composed music and organized special effects, then such a play becomes a project. In the conditions of a mainstream school and the limited resources, the organization of school-wide project activities, involving collective management, seems to us the most expedient. Accordingly, by project-collective management we mean collective activity in the management and implementation of school-wide projects with the involvement of all participants in the educational process and social partners of the school.

The hypothesis of the study is the assumption that the implementation of long-term largescale projects in a mainstream school, in which various subjects of educational relations and social partners of the school are involved, will contribute to the development of the school staff, if these projects are managed collectively.

The purpose of the study is to build a model of project-collective management in the development of the school team. The scientific novelty of the proposed approach consists in a combination of the actual project form of organizing school educational activities and the collective form of managing the process of implementing these long-term school-wide projects, which contributes to solving pedagogical problems of developing the individuality of participants in educational activities and the formation of their communicative competencies. 


\section{METHODOLOGY}

We analyzed normative documents in the field of education and scientific literature on the problem of the study, accumulated pedagogical experience, and made conclusions on the results of the experimental work. In the course of organizing and conducting the experiment, such general scientific methods of theoretical research as analysis, synthesis and modeling were used. Observation, questionnaires, case studies, content analysis of the products created during practical activities of the participants in the experiment and mathematical processing of the data were used as experimental methods. In the Federal Law "On Education in the Russian Federation" the concept of "self-government" is replaced by the term "collectivity" (Federal portal "Russian education"). This approach activates the participation of the educational activity subjects in school management, since collectivity presupposes the coordination of most managerial decisions with the whole school staff, as well as the involvement of a wide range of participants in the development of these decisions and control over their implementation. However, today only an insignificant part of the collegial bodies' powers presupposes the solution of essential questions in the organization of school life (Kamenskiy, 2009). The basic principles of scheduling, the volume and content of the academic load, the ways and standards of funding are determined not by the school itself, but by the governing documents. In practice, collegial bodies can be most active, first of all, in the extracurricular activities of the school, which is inextricably integrated with the educational activity, but is less regulated and helps to reveal the creative potential of the participants to the greatest extent. We find project method the most appropriate for introducing in the school activity, bearing in mind large-scale school-wide projects that affect the life of one school, but also the surrounding community (Kamenskiy \& Karyagin, 2019).

The organization of the project schoolwork was carried out in several stages. The first stage (2014-2015) is a theoretical and exploratory one, including analysis of the literature and the study of approaches to developing a model of interaction between subjects of the educational process in the implementation of socially oriented long-term school-wide projects. The second stage (20162018) is an experiment, aimed at substantiating and testing the developed model. The third stage (2019-2020) includes comparison, generalization, analysis, systematization of the results of theoretical and experimental work, determining the impact of the implemented model on the team building capacity of the school staff, processing and formalizing the research results.

The modern educational environment of the city is incredibly diverse. Today, both the state network of additional education and the system of private educational organizations, like museums, exhibitions, development centers, and interest clubs are widely deployed. This educational potential of the city should be realized. A high degree of diversity in the infrastructure of the educational space also gives rise to the risks of inconsistency of actions in the interaction of subjects of educational activity. We proposed a cluster approach to overcome the mismatch. Each school subject cluster has pedagogical partners, like neighboring schools, universities, libraries, museums, scientific communities, public associations, and creative unions. In a cluster, a student is the systemforming factor, who carries the pedagogical result. The construction of the cluster is based on the leading pedagogical ideas in the development of the participants' individuality in the educational process, the pedagogy of authority, which is the antipode of authoritarian pedagogy (Kamenskiy, 2009). Agreement and mutual trust can arise only when a child interacts with people who are truly authoritative for him.

We used as the main methodology the well-known and tested for a long period in various educational organizations the method of the educational environment examination by V.A. Yasvin. With this method, we checked the effectiveness of the project-collective management implementation and its impact on the development of the school team. We were basing on a preliminary ranking of the studied parameters and the determination of the specific weight of each of them. We modified this method in accordance with the needs of the experiment. 
Both at school and at home, a child needs an environment in which he feels significant, needed by other people, capable of expressing his own individuality (Gagin \& Dmitriev, 2000). The formation of his/her personality takes place in activity, but it should be an activity organized not by compulsion, but independently, in which he/she should be responsible for the made decisions and their implementation (Eckert, 2018; Miller, 2016). This position is designated by the federal state educational standard.

\section{RESULTS}

Thanks to the project-collective management model, which was implemented during the entire period of the study, there was a positive trend in the relationship between the participants in the educational process. Teachers, parents and schoolchildren, engaged in specific, socially oriented activities, were better able to get to know each other, to appreciate the uniqueness and strong points of each participant.

An example of such a large-scale project is the "Dobraya Lyra" literary and pedagogical competition, which purpose is to familiarize students with independent thoughtful reading. This educational practice was initiated by students and teachers of Krasnoselsky district of SaintPetersburg more than ten years ago. The essence of the project is to conduct a literary competition for professional writers for the best work of schoolchildren, where teachers and parents act as experts. The partners of the project are the Saint-Petersburg Union of Writers, the Union of Writers of Russia, the newspaper "Rossiyskiy Pisatel", the Academy of Postgraduate Pedagogical Education of Saint-Petersburg, Herzen Pedagogical University, Russian Gymnasium Union and many other interested partners. As a result of the implementation of the project, eleven volumes of contemporary works of art have already been released, intended for reading by schoolchildren. The works are accessible through the website created by students who are members of the organizing committee of the competition. All stories of contemporary authors - winners of the competition, are actively read by schoolchildren from different regions of the country, since more than twenty partner schools are involved in the project.

The "Dobraya Lyra" project is organized in several stages. At the first stage, a large-scale information and educational campaign is carried out using regional and federal media. Project materials, such as the Competition Regulations, the composition of the jury, the criteria for choosing the winners, are posted on the competition website, on the websites of the regional branches of the Union of Writers of Russia, in the pedagogical publications "September 1", "Public Education", "September". After analyzing the information, the organizing committee decides on the collection of applications from the authors. The main incentive for professional writers to participate in the competition is the obligation of the organizers to ensure a thoughtful reading of the submitted works by children, parents and teachers. At the second stage, the socio-pedagogical jury chooses the best from the read, and then the short-list of the leading works is submitted for examination to a professional jury consisting of members of the Unions of Writers. The selected works then compose the collection "Dobraya Lyra". Every year about five hundred authors from various regions of our country, neighboring and distant foreign countries take part in the competition.

Then the key stage of the competition begins. Readers begin to purposefully work with the selected materials. Then comes the children's stage of the competition, in which various nominations are announced, such as the best "drawing", "hand-made article", "book trailer", "essay on what was read", "letter to the author" and others. Students in this project are directly involved in the living literary process. Meetings with winning authors, discussions about what has been read, the opportunity to choose for conversation the work that you like best, all this is in the zone of interests of both the school itself and its social partners. This format of mutual interest in carrying out project activities, containing pedagogical content, is in high demand for our school today. 
At each stage of the project's implementation, key decisions are made collectively, whether it is the formation of a short list or the definition of open nominations. Thus, a real child-adult community is formed, in which everyone feels their importance and indispensability, having the opportunity to express their own judgment and influence the final result.

At the beginning of the experiment, the schoolchildren participating in the project, and as a result there were more than a thousand of them, admitted that they hardly read fiction of their own choice, and the reading circle is limited only to the classics that are compulsory for study. Now more than eighty percent of the students involved in the "Dobraya Lyra" project form their own reading circle, as evidenced by regular polls conducted online through the competition website. The general atmosphere in the school team has also changed. At the initial stage, more than thirty percent of the project participants were not sufficiently satisfied with the relationship with each other. Today there are practically no such schoolchildren and adults. The general creative atmosphere that arises during meetings with bright, extraordinary people, the corresponding emotional mood is transmitted not only to the participants in project activities, but also to the entire school team, which values the state of continuous eventfulness, expectations of a holiday in which everyone has the opportunity to be not just as a participant, but as the creator of the event. Participants in the educational process become more open, the level of mutual trust increases, and not only working, but also personal relationships develop (Kamenskiy, 2018; Scribner et al., 2007). On the whole, the general mood of the school staff becomes more positive and uplifting, which inevitably affects such formal indicators as student performance and the quality of knowledge.

Another striking example of a school-wide, large-scale, long-term project is the "School Patent" competition. It assumes active interaction of students with the scientific community of the city and country, authors and inventors. The competition is held for schoolchildren and is aimed at supporting their desire to find new solutions, coming up with unexpected ways out of various nonstandard situations, invention. Various nominations of the competition cover both technical and humanitarian fields of knowledge. For example, the "drawing" nomination assumes not so much the quality of the image, but the idea that a child puts into his/her work. The "essay" nomination takes into account not the quality of the author's style, but the thoughts embedded in the text.

In addition to diplomas, certificates and valuable gifts, students receive support from the organizers of the competition in obtaining a copyright certificate, a patent for inventions made by students. And the most outstanding works of students are supported by enterprises that are ready to introduce them into real production. Summing up the results of the "School Patent" project, schoolchildren demonstrate striking inventions, such as a heating system for rooms in extremely cold winters with an efficiency twice as high as conventional ones or an individually formed set for survival in extreme conditions. The founders of the project and experts from the organizing committee of the competition, members and specialists of the jury from ITMO University, the Ministry of Defense of the Russian Federation, Rospatent of the North-West noted the high level of creative activity of the project participants.

A long-term (ten years) project "School patent" includes organized meetings of students with inventors at the House of Scientists, interaction of schoolchildren from different regions of Russia through videoconferencing held by the Education Support Fund (Gazprom), which has more than three hundred studios in various regions of our country, as well as joint development of children and adults. Scientists, patent attorneys, and intellectual property specialists communicate with children on a regular basis with authentic enthusiasm.

Thanks to participation in the implementation of this project, schoolchildren get acquainted with the basics of inventive activity, begin to comprehend issues of copyright and intellectual property. Key decisions on the implementation of the School Patent project are made collectively, in the interaction of the child and adult communities. The final result of the project represents not only increased children's inventive activity (at the first stages of the project, only one or two school 
inventions were patented, and now seven or eight copyright certificates are issued), but the general positive attitude of schoolchildren, their creative activity, an increased desire to offer non-standard solutions, share ideas with adults.

As a result of the introducing of the project-collective management model for the development of the school staff, the relationship of the participants in the educational process has noticeably changed, as evidenced by the data of the research conducted by the team of authors, which lasted for ten years and included 1200 students from various schools in the city, 340 teachers and 520 parents of schoolchildren. The data indicating the degree of satisfaction with classmates after joint participation in large-scale project activities, regardless of the type of this activity, throughout the entire experiment grew by $25-30 \%$ over the year, and the degree of satisfaction with the quality of educational services increased by an average of $15-20 \%$, while a low degree of satisfaction with educational activities among the participants in the experiment is practically absent. Relations between schoolchildren and teachers are noticeably improving. This indicator in each group of participants grew by $30-35 \%$ over the year, regardless of the nature of the project activity. The parents' attitude to school also changed. Those parents who entered the collective bodies of the project management got a better understanding of the specifics of the school's work, its weak and strong points. Their level of satisfaction with the organization of school life increased by $20-25 \%$. At the same time, it should be noted that school-wide project activity does not interfere with the main educational activity, but, on the contrary, supplements it, motivating students to deeper master the main school subjects. This is proved by the performance data of schoolchildren participating in the project-collective management, which exceed the citywide level by 15-20 points over many years of the experiment.

The social partners involved in the implementation of school-wide long-term projects become, over time, a kind of circle of friends for the educational organization, which inevitably increases the general educational potential of the school. Given the limited allocated resources, this circumstance is of particular importance.

Thus, as a result of the comprehensive interaction of schools with social partners within the framework of the "Dobraya Lyra" project, agreements on long-term cooperation were concluded with such organizations as the Union of Writers of Russia, the newspaper Rossiyskiy Pisatel, the Center for Contemporary Literature and Books of St. Petersburg, the Saint-Petersburg Academy of Culture, Herzen Russian State Pedagogical University, Academy of Postgraduate Pedagogical Education.

Now students of basic experimental schools No. 289 and No. 590 have the opportunity to use additional learning resources in the expanded educational space. Our schoolchildren regularly take part in the Union of Writers of Russia, together with teachers and parents in literary evenings and creative meetings with authors. Members of art community repeatedly visit students at schools. The participants of the "Dobraya Lyra" project are in regular correspondence with the editorial staff of the federal newspaper "Russian Writer", now this newspaper has found an opportunity to cover the news of each stage of the literary and pedagogical competition. The Center for Contemporary Literature and Books invites children to take part in their events. Schoolchildren participate in literary quests, poetry meetings, and discuss their own literary work with professionals. Together with the Academy of Culture, a new large project for the modernization of school libraries was organized, which involves not only the digitization of book sources, but also changes in the basic principles of the children's library, shifting its functionality towards much greater interactivity. Herzen Russian State Pedagogical University included our schools in the number of educational institutions of his educational district. For several years, schoolchildren and teachers have been taking an active part in the large-scale university program of "pedagogical seasons", where communication with interesting persons of the city and celebrities is organized. Finally, the Academy of Postgraduate Pedagogical Education hospitably opened its doors for the international 
ceremony of presenting awards and prizes of "Dobraya Lyra" project. This solemn event has been held in the halls of the Academy for several years. Authors not only from all over our country, but also abroad come to present the winners' diplomas. There is a serious, thoughtful conversation between adults and children about the fate of culture, creativity, a person's place in the world.

The "School Patent" project has also a great pedagogical effect. Organizations such as ITMO University, Rospatent of the North-West, the All-Russian Society of Inventors and Innovators (ARSII), the Association of Technology and Innovation Support Centers, and the Ministry of Defense of the Russian Federation have become permanent partners of schools on a long-term basis.

The permanent participants of the "School Patent" project, after a collective discussion of each stage, make a decision on a particular format of interaction with the competition partners. So, for example, within the framework of the project implementation, schools has to communicate most closely with Rospatent at the stage of examination of the participants' applications in order to correctly determine the novelty in the applications and solutions sent to the competition. ARSII members speak with children and give lectures in person or online about the basics of inventive activity. ARSII made possible to organize the All-Russian Forum of Young Inventors in Kazan "Intellektualniy budilnik", which is attended by both schoolchildren and adults from all over the country. The programs of these meetings are very eventful. Children have the opportunity not only to discuss the theoretical issues of creativity, but also to get acquainted with the practice of organizing innovative activities, having visited the Kazan Helicopter Plant, or the University campus of Innopolis. Thanks to the efforts of the Association of Technology and Innovation Support Centers (ATISC) in the basic schools of our experiment, it was possible to open completely new infrastructural divisions of the $3^{\text {rd }}$ level of ATISC, which main task is to give the competences for behavior in matters of copyright and intellectual property rights protection, as well as to promote invention and creativity. Students, parents and educators were enthusiastically involved in this work. The interaction of the "School Patent" project with the Ministry of Defense of the Russian Federation was especially close. Several years ago, a decision was made at a collective discussion to introduce a new nomination of the competition "Things necessary for the defense of the country through the eyes of children", the proposals of the children in this nomination have become continuous. New options for equipping military personnel, remote ammunition clearance systems, new principles of heating systems for military personnel in the northern regions, and much more. Now our schoolchildren are regularly invited by the Ministry of Defense to the summer international army forums in the Patriot Park, where the annual results of the "School Patent" are now summed up. The children's speeches arouse genuine interest not only among ordinary military personnel, but also among the generals.

In addition to the two largest projects, a similar effect of expanding the educational space of the pupils and the development of school collectives in general is observed in other project areas. For example, the oldest project "School Exhibition Gallery of Professional Painting" has gathered significant partners as the Exhibition Hall of the Union of Artists of Saint-Petersburg, the Museum "Literature. XX Century", Museum "Raznochinny Petersburg", Museum "Old Photography" named after Karl Bulla and other organizations and individuals.

The South Coast Olympic Games project has generated close cooperation with sports organizations and clubs. As a result of this interaction, a basketball academy "Zenith" was opened on the basis of the experimental ball school, and the boxing tournament named after N.S. Valuev became an annual competition of the All-Russian sports calendar and led the project to the opening of the Nikolai Valuev Boxing School at the experimental school, which now has more than a hundred students.

The project "Intraschool monetary system", aimed at teaching students the basics of financial literacy, has grown into an even larger project "Our School City", which main task is to educate a citizen who takes an active and conscious participation in the political life of the city and 
country. Both projects have spawned multiple relationships between schools, economic and political structures such as the Chamber of Commerce, the Union of Entrepreneurs, the local Municipal Council, the City Legislature, and other associations. Schoolchildren were given the opportunity to meet regularly with entrepreneurs, politicians, and public figures. They learn to conduct a dialogue, ask questions, analyze, debate, defending their point of view based on competent argumentation. These skills are included in the educational standard, the formation of the corresponding personality traits of the graduate affects the overall quality of education, which is provided by this educational organization.

Naturally, such activity unites the participants in educational relations, blurring the boundaries between people of different generations on the basis of interaction in organizing a common thing that is important for all participants. At the meetings of collective project management bodies, an atmosphere of goodwill and constructive criticism reigns. The main task of the participants is not to test a person's skills and knowledge, but to help in acquiring new ones. An additional effect of project-collective activity is a continuous search for new forms of educational activity, constantly emerging proposals to expand the range of topics discussed and issues to be addressed, the search for new necessary partners, the emergence of new projects and programs for their implementation, the addition of existing programs with new meaningful materials, adding new developments.

\section{DISCUSSION}

Many studies are devoted to the organization of project activities of schoolchildren. However, much less attention is paid to the project activities of the school as an organization. Accordingly, the relationship between the project form of the educational process, the arrangement, development, team building of the school staff, the constant search for new ways to increase the human capital of the school are not observed.

The experience of organizing project activities in the educational process accumulated over the past decades, starting from the twenties of the last century (Collings, 1926; Dewey, 1994; Kilpatrick, 1921; Komarovsky, 1967; Krupskaya, 1962; Shatsky, 1980; Wentzel, 1923; Yegorov, 2002). Today it is not applicable without a serious correction. The time of narrow specialization, simple labor operations and relationships has gone. The very understanding of the method of projects in education as "a way to achieve a didactic goal through a detailed development of a problem (technology), which should end ... with a practical result, formalized in one way or another ..." requires an updated interpretation (Polat, 2010). It is often impossible to detail the problem declared in the development, due to its globality or complexity of the structure. For example, research into the creation and possible use of artificial intelligence or the consideration of environmental aspects in the organization of modern production often does not imply unambiguous conclusions or step-by-step recommendations. At the same time, the result obtained during the implementation of an educational project cannot always be and should be formalized in a traditional way, being sometimes delayed in time or consisting in changes of the participants, and not of the external environment. That is why the effectiveness of the school's collective project activities should first of all be measured not by quantitative but by qualitative indicators, among which the self-awareness of each participants occupies a significant place. In turn, personal self-awareness is largely determined by the general mood of the team. At the same time, there is an inverse relationship. The collective mood is determined by the mood of each participant of the activity. Today, collectivity has become an integral part of our life. The problem of collectivity and collective management occupies a special place in the education system.

A sufficient number of works are devoted to the issues of collective management in the educational field, in which it is considered as a special management style or organizational climate (Kabushkin, 2009; Potashnik, 2011; Shamova, 1992), as collective management of an educational 
organization (Frumin, 2015; Ushakov, 2011), as a concept for the theory of command management (Boddy \& Peyton, 1999; Nemov, 1994). However, for the most part, the authors consider collective management not in conjunction with school-wide project activities.

Our research has shown the high efficiency of combining two lines of the modern education development, like the project approach and collective management of the educational organization. Since the scale of the projects and the duration of their implementation assumed a wide coverage of all areas of the school's activities, the collective management decisions influenced the organization of the entire educational process of the school and the development of the school staff in general. Thus, participants in project activities fully felt a measure of personal responsibility for made decisions, therefore, before deciding on the organization of a particular step in project interaction, the existing international experience in the implementation of such pedagogical practices was carefully studied. For example, the program "School as a City", widely known in Western countries, had its own certain risks associated with a certain fragmentation of the educational process, possible loss of systematicity of the knowledge acquired by the child (Bukvić et al., 2020; Targeted News Service, 2020). To avoid such negative consequences, a collective decision was made to transfer the main activity in the field of project activities within schoolchildren's after school hours. This made it possible to preserve the traditional educational process without violating its integrity.

An unexpected effect of the experiment was a significantly increased interest in cooperation between the school's social partners (Erastus \& Grant, 2020; Rainford, 2014). Since the implemented projects carry a positive component for the development of not only the school itself, but also the surrounding society, the response is naturally quite justified. Now the social partners of the school began to initiate some lines of development for the school staff. They offer new proposals more often.

Therefore, for example, the initiative to open a memory alley on the territory of the basic school in honor of the seventy-fifth anniversary of the victory of our country in the Great Patriotic War came from the deputies of the local municipal council. Our pupils actively participated in the implementation of this initiative, searched for relatives, those heroes who fought on the territory where the school is now located, studied in detail the biographies and circumstances of the feat, invited veterans to the grand opening of the star walk of fame. As a result of the project, pupils, together with municipal deputies, created a separate project site with the prospects for its further transformation into a virtual museum of the history of our region, which will include headings not only purely historical, but also eventful, such as "outstanding people of our land", or "Great places", "development prospects" and other sections.

Accordingly, we believe that the indicated hypothesis has been confirmed. The collectivity of school project management influences its development. At the same time, a certain feedback was revealed. The development of the school and the surrounding society determines the team building capacity of the school staff.

\section{CONCLUSION}

The result of a ten-year experiment, which consisted in a radical restructuring of the basic educational organizations' work, changes in the development and management systems, demonstrated the high efficiency of the implemented model. The collective governing bodies of long-term large-scale educational projects with a social orientation included various participants in the pedagogical process (pupils, their parents, teachers, administration, social partners of the school). The real necessary interaction of all stakeholders on the basis of a lively, interesting activity for everyone, increased motivation to search for new, non-standard solutions, contributed not only to the team building of the school staff, but also to the development of the educational organization in general, which consists in enriching its infrastructure, harmonizing interpersonal relations, 
establishing a dialogue between representatives of different generations, a general positive attitude of all subjects of educational relations.

Project-collective management plays a positive role in the formation and development of the school staff, sets up the participants of educational activities in a positive mood, activating their creative abilities, promoting the development of independence, forming their unique individuality in socially useful activities. The variety of content and forms of school-wide projects helps to involve almost all participants in the educational process, depending on the interests and preferences of each student and teacher. The presented materials can be used for work not only by school directors, but also by teachers and educators of additional education.

Authors' Contributions: Alexey M. Kamenskiy: conception and design, acquisition of data, analysis and interpretation of data, drafting the article, critical review of important intellectual content. Sergey N. Kariagin: conception and design, acquisition of data, analysis and interpretation of data, drafting the article, critical review of important intellectual content. All authors have read and approved the final version of the manuscript.

Ethics Approval: Not applicable.

Acknowledgments: Not applicable.

\section{REFERENCES}

Boddy, D., \& Peyton, R. (1999). Fundamentals of management. Saint Petersburg: Piter.

Bukvić Ivana Bestvina, Buljubašić Iva, \& Ivić Marija. (2020). Project management education in Croatia: A focus on the IT sector needs. Journal of Contemporary Management Issues, 1(25), 255-278.

Collings, E. (1926). Experience of the American school on the method of projects. Moscow: Novaya Moskva.

Dewey, J. (1994). Democracy and Education. N.Y.: Collier Macmillan Ltd.

Eckert, Jonathan (2018). Collective Leadership Development: Emerging Themes From Urban, Suburban, and Rural High Schools. Educational Administration Quarterly, 55 (3), 477-509.

Federal portal "Russian education". ITT research Institute. Russian education. Retrieved from: http//www.edu.ru. Frumin, I.D. (2015). Educational practice supporting adulthood. Educational policy, 4 (70).

Gagin, Y.A. \& Dmitriev, S.V. (2000). Spiritual acmeism of biomechanics. Saint Petersburg: BPA.

Kabushkin, N. I. (2009). Fundamentals of management-textbook. Moscow: Novoe Znanie.

Kamenskiy, A.M. (2009). Intra-School educational cluster. National education, 9, 90-93.

Kamenskiy, A.M. (2018). School and society: preconditions, reality, tendency interactions. Educational and methodological guide. Saint Petersburg: LOIRO.

Kamenskiy, A.M. \& Karyagin, S.N. (2019). Distributed management in the development of social partnership of basic education organizations with sports orientation. People and education, 3, 4-8.

Karanja, Erastus \& Grant, M. Donna (2020). Evaluating Learner-Centeredness Course Pedagogy in Project Management Syllabi Using a Content Analysis Approach. Journal of Information Systems Education, 2(31), $131-146$. Retrieved from: https://aisel.aisnet.org/jise/vol31/iss2/6

Kilpatrick, W. (1921). Dangers and Difficulties of the Project Method and How to Overcome Them: Introductory Statement and Definition of Terms. Teachers College Record, Volume 22, Number 4.

Komarovsky, B.B. (1967). Russian pedagogical terminology. Moscow: Prosveshchenie.

Krupskaya, N.K. (1962). Pedagogical essays: in 11 volumes. Vol. 10, Moscow.

Lo, R., \& Brown, R. (2000). National Library of Medicine. Collegian. Royal College of Nursing (Australia), 4 (7), 8-10, 123.

Makopoulou, Kyriaki \& Armour, Kathleen (2013). Possibilities and challenges in teachers' collegial learning.

Educational Review, 66(1), 75-95. 
Miller, Robert James, Goddard, Roger D., Minjung Kim, Jacob, Robin, Goddard, Yvonne \& Schroeder, Patricia (2016). Can Professional Development Improve School Leadership? Results From a Randomized Control Trial Assessing the Impact of McREL's Balanced Leadership Program on Principals in Rural Michigan Schools. Educational Administration Quarterly, 52 (4), 531-566.

Nemov, R.S. (1994). Psychology. Book 1. Moscow: Prosveshchenie: Vlados.

Polat, E.S. (2010). Modern pedagogical and information technologies in the education system. Moscow: Academia.

Potashnik, M.M. (2011). Exclusive aspects of school management. Moscow: Pedagogical society of Russia.

Rainford Karen, J. (2014). Saint Mary's University of Minnesota. ProQuest Dissertations Publishing.

Salleh Hairon, \& Clive Dimmock. (2011). Singapore schools and professional learning communities: teacher professional development and school leadership in an Asian hierarchical system. Educational Review, 64 (4), $405-424$.

Scribner, Jay Paredes, Sawyer, R. Keith, Watson, Sheldon T. \& Myers, Vicki L. (2007). Teacher Teams and Distributed Leadership: A Study of Group Discourse and Collaboration. Educational Administration Quarterly, 43(1), 67-100.

Silva, L. R., Santos, A. R., \& Santos, I. T. R. (2020). Public policies for education of/in the field and the school environment in a settlement of the MST: the intimate relationship with the pedagogical policy. Journal of Research and Knowledge Spreading, 1(1), e11737.

Shamova, T.I. (1992). Research approach in school management. Moscow: APPCITP.

Shatsky, S.T. (1980). Selected pedagogical works in two volumes. Moscow: Pedagogika.

Targeted News Service. (2020). Washington, D.C., 29 May 2020.

Ushakov, K.M. (2011). School Management: crisis in the period of reforms. Moscow: Sentiabr.

Wentzel, K.N. (1923). New ways of upbringing and education of children. $2^{\text {nd }}$ Ed. Moscow: Zemlia I Fabrika.

Yee Fan Tang, Sylvia \& Lin Choi, Pik (2009). Teachers' professional lives and continuing professional development in changing times. Educational Review, 61(1), 1-18.

Yegorov, S.F. (2002). History of pedagogy in Russia. Moscow: Academia, pp. 372-379.

Received: 21 March 2021 | Accepted: 24 April 2021 | Published: 02 May 2021

This is an Open Access article distributed under the terms of the Creative Commons Attribution License, which permits unrestricted use, distribution, and reproduction in any medium, provided the original work is properly cited. 